\title{
AXIAL AND RADIAL EVALUATION OF THE BASIC DENSITY AND FIBER DIMENSIONS OF Guazuma crinita MARTIUS WOOD
}

\author{
Manuel Chavesta Custodio ${ }^{1}$, Mario Tomazello-Filho ${ }^{2}$, Mayara Elita Braz Carneiro ${ }^{3}$, Silvana Nisgoski ${ }^{*}$ \\ ${ }^{1}$ Universidad Nacional Agraria la Molina. Departamento de Industrias Forestales, Lima, Perú - e-mail: mchavesta@lamolina.edu.pe \\ ${ }^{2}$ Escola Superior de Agricultura “Luz de Queiroz", Piracicaba, São Paulo, Brasil - e-mail: mtomazel@esalq.usp.br \\ ${ }^{3}$ Universidade Federal do Paraná. Curitiba, Paraná, Brasil - e-mail: mayaraelita@ufpr.br \\ ${ }^{4 *}$ Universidade Federal do Paraná. Curitiba, Paraná, Brasil - e-mail: nisgoski@ufpr.br
}

Received for publication on 12/03/2018 - Accepted for publication on: 31/10/2019

\begin{abstract}
Resumo
Avaliação axial e radial da densidade e dimensões básicas de fibras em madeira de Guazuma crinita Martius Este trabalho teve por objetivo avaliar a variação radial e axial da densidade básica e das dimensões das fibras da madeira da árvore Guazuma crinita Mart. Foram usadas dez árvores com idades de cinco e de oito anos oriundas de plantações florestais do setor de Maquizapallo, localizado na cidade na cidade de Puerto Inca, Huánuco, no Peru. As variáveis analisadas foram a densidade básica tendo por referência a norma NTP 251.011: 2014, e as dimensões das fibras. As árvores foram derrubadas e seccionadas em pedaços de 4 metros, divididos em três partes - basal, média e apical - para a determinação da densidade e avaliações das fibras. Em geral, a densidade básica e as características anatômicas avaliadas diminuem da base para a ápice; desse modo, estas aumentam da medula para o córtex, no que a idade da árvore teve influência significativa na densidade básica mas não nas características anatômicas; não obstante, por ser a densidade básica maior para 8 anos seu emprego poderia ser em usos que não exijam suportar grandes esforços e ser usada comercialmente. Palavras-chave: bolaina blanca ("moço branco"), características anatômicas, propriedades físicas.
\end{abstract}

\section{Abstract}

The objective of the work was to evaluate the radial and longitudinal variation of the basic density and fiber dimensions of the Guazuma crinita Mart. Ten trees of five and eight years were used. They came from forest plantations of Maquizapallo located in the city of Puerto Inca, Huánuco - Peru. The variables analyzed were basic density based on the standard NTP 251.011: 2014, and the fibers characteristics. The trees were felled and sectioned into 4-meter logs, divided into three parts basal, middle and apical for density determination and fiber evaluations. In general, the basic density and the anatomical characteristics evaluated decrease from the base to the apex, meanwhile, they increase from the marrow to the cortex where age had a significant influence on the basic density but not on the anatomical characteristics, however, since the basic density is greater for 8 years, it could be used where no great effort is needed and also commercially.

Keywords: bolaina blanca, anatomic characteristics, physical properties.

\section{INTRODUCTION}

In South America the plantings are composed by species with short cycle and rapid growth, especially Pine and Eucalyptus; however, when wood from other species is considered, mostly the natives, the awareness about its properties or previous experience of use in industrial scale are small (VALENTE et al., 2013). Peru is the country with the biggest delay in the continent on reforestry matters, even though there are 10,5 million of hectares suitable to reforestry plantations. The surface, according to official data, does not reach $10 \%$. One of the main causes is the scarce development of knowledges that facilitate to increase productivity and competitivity in the reforestry sector, being of high priority the generation of scientific and technological knowledge to produce quality wood (SERFOR, 2016).

Guazuma crinita ("bolaina blanca", or "moço branco") is a species to wood use of rapid growth, deriving from secondary forests, becoming in the last few years a species with good potential to its manufacturing, processing and commercialization (PUTZEL et al., 2013). The demand for this wood grew significantly, standing out among the twenty main species exploited in national-level (SERFOR, 2016), reaching a volume of wood in logs of $56119,05 \mathrm{~m}^{3}$ and of $3118,06 \mathrm{~m}^{3}$ in the case of already sawed wood, enabling the public and private sectors to establish plantations of this species, because of its short rotation cycles and high productivity, making it possible to obtain profits in short-term when compared to wood products derived from primary forests (IIAP, 2009). In 2018, the country had about 20 thousand hectares of "bolaina blanca". The more moderate projections indicate that this species witll reach around 200 thousand hectares in 2025 (SOUDRE, 2019).

The distribution of Guazuma crinita is wide in the neotropics, ranging from Central America to Brazil in the amazon region. In terms of altitude, it is found until $1500 \mathrm{~m}$ above sea-level. The trees reach diameters of 25

FLORESTA, Curitiba, PR, v. 50, n. 2, p. 1143 - 1150, abr/jun 2020

Custodio, M. C. et.al.

ISSN eletrônico 1982-4688

DOI: $10.5380 /$ rf.v50 i2.58356 
to $80 \mathrm{~cm}$ and 15 to $30 \mathrm{~m}$ of total height, with straight trunk and ramifications since the last third (REYNEL et al., 2003). It belongs to the Malvaceae family, being an important species to reforestry and agroforestry plantations in the peruvian amazon basin, serving as an indicator of fertility of the soil and growing rapidly, with the rotation age of 6 to 12 year in the Peruvian Amazon. The trees grow in dense plantation areas of until 1200 specimen/hectare in young fallow (<3 years) and until 500 mature trees $(\geq 25 \mathrm{~cm}$ of DBH - Diameter at Breast Height) by hectare after handle (IIAP, 2009; WEBER et al., 2011).

The quality of the wood is linked to its anatomy and physical and mechanical qualities, Anatomically, in the tropical species of America, it has been observed different patterns of variation in the celular dimensions, which is explained by the activity of the changing cells. They produce along a certain period elements of bigger dimensions, until reaching estabilization in more advanced ages along the radius of the tree. The fibers located in the rings of growth closer to the marrow present smaller dimensions than the ones situated in the growth rings closer to the corex of the trunk (VALENTE et al., 2013; LIMA et al., 2011). For example, the lenght of the fiber until the cortex are referred in the Gallesia integrifolia (ANDRADE et al., 2009), the Cariniana legalis (GARCIA et al., 2009), the Anadenthera colubrina (SUCKOW et al., 2009) and Anadenanthera peregrina (VALENTE et al., 2013). It was also noted a enlargement in the thickness of the wall of fiber and a reduction in the diameter and lumen of the marrow fibers in relation to the cortex. Although, Zanon et al., (2008) did not observe significant statistics variations in Croton floribunda, in Piptadenia gonoacantha, and Longhi et al. (2010) also did not find clear tendencies of variation in the diameter of the fibers.

At the same time, regarding physical properties, the density is an indicative of wood quality, constituting a good index to various purposes, being a feature capable of genetic improvement and considered highly transferable by inheritance (trautenmüller et al., 2014). The density is explained by the heterogeneous structure, as consequence to the growth of the tree: extemely complex porcess and influenced by climate, soil, competition among trees, forestry techniques and age. Even so, differences in the density according to axial and radial position of the tree are found (IGARTÚA; MONTEOLIVA, 2010). Thus, for example, axially the density in Ficus insipida enlarges the base to the apex, and radially the marrow to the cortex.; in Amburana cearenses, Portal et al. (2019) found the same radial behavior, In the broad-leafed of diffused porosity species, it is to expect density variations even among trees, despite the strong genetic determinism, because there are found differences among trees of the same location and age (DOWNES, cited by IGARTÚA AND MONTEOLIVA, 2010). Therefore, this variability has an impact in its industrial use, because it affects the final productl (LIMA et al., 2011).

The wood density of the Guazuma crinita varies genetically according to its origin. The results according to its origins and tests of procedence suggest that the sources of rapid growth can be selected in a younger age without reducing significantly the density of the wood (WEBER; SOTELO-MONTES, 2008). Likewise, evaluations of variation among the main physical properties, according to its sources, cope with the significative statistcs differences in a the physiscal properties, except the density of green wood (TUISIMA-CORAL et al., 2017).

The data of average basic density of the wood of Guazuma crinitia at eight yars of age is $433 \mathrm{~kg} / \mathrm{m}^{3}$ (TUISIMA-CORAL et al., 2017), number slightly biggger than Weber e Sotelo-Montes (2008) reported to 32 months $\left(417 \mathrm{~kg} / \mathrm{m}^{3}\right)$. This variation is due to environmental factors, with low influence of age, because it is susceptible to strong genetic control (TUISIMA-CORAL et al., 2017). Reports about basic density indicate that it is bigger in the base are than the superior part of the trunk; besides that, the trees had lower density and bigger differences between the inferior and superior portions of the trunk, but this relations depended on the source of the seed and the growth zone (WEBER; SOTELO-MONTES, 2008), as well as the variation in radial direction, just as in the longitudinal direction are related to the age of the tree, the sample, the genotype and environmental conditions.

The study of the characterization of the wood of Guazuma crinita is justified according to the very few existent information about the variability of the wood derived of plantations, since the present work had as objectibe to evaluate the base density and fiber dimension, as well as its internal variation in longitudinal and radial direction, looking to a better knowledge of its technological properties, relating it to quality parameters.

\section{MATERIALS AND METHODS}

The wood of Guazuma crinita is derived of forestry plantations of the Maquizapallo sector, in the city of Puerto Inca, Huánuco, Peru; geographically located in the coordenates 9³7'43' 'South and 74058'28' West; with $145 \mathrm{~m}$ of altitude (Figure 1). The zone presents an annual average of precipitation of $2482 \mathrm{~mm}$, with minnimum temperature of $22^{\circ} \mathrm{C}$ and maximum $35^{\circ} \mathrm{C}$. The plantation soil is alluvial, with loamy texture and silty loam; $\mathrm{pH}$ de 5,5, organic matter of 4\%; CIC of 10,8 meq/100g and effective depth bigger than $90 \mathrm{~cm}$. The wood samples were collected in field in november/2016. The spacing between trees was $3 \times 3 \mathrm{~m}$. The characteristics of trees are shown in the Table 1. 
Tabela 1. Dados dos espécimes amostrados.

Table 1. Data from evaluated trees.

\begin{tabular}{ccccc}
\hline Age & $\mathbf{N}^{\circ}$ individual & DBH(cm) & H total (m) & H omercial (m) \\
\hline & 1 & 18,8 & 16,0 & 12,8 \\
5 years & 2 & 21,6 & 17,4 & 15,4 \\
$(\mathbf{6 3}$ months) & 3 & 21,6 & 17,0 & 13,2 \\
& 4 & 22,0 & 17,5 & 14,8 \\
& 5 & 21,3 & 16,0 & 13,4 \\
\hline & 1 & 26,4 & 25,0 & 20,6 \\
$(\mathbf{1 0 3}$ months) & 2 & 27,7 & 26,0 & 21,3 \\
& 3 & 27,1 & 20,0 & 15,9 \\
& 4 & 26,1 & 22,0 & 18,0 \\
& 5 & 26,1 & 19,0 & 15,9 \\
\hline
\end{tabular}

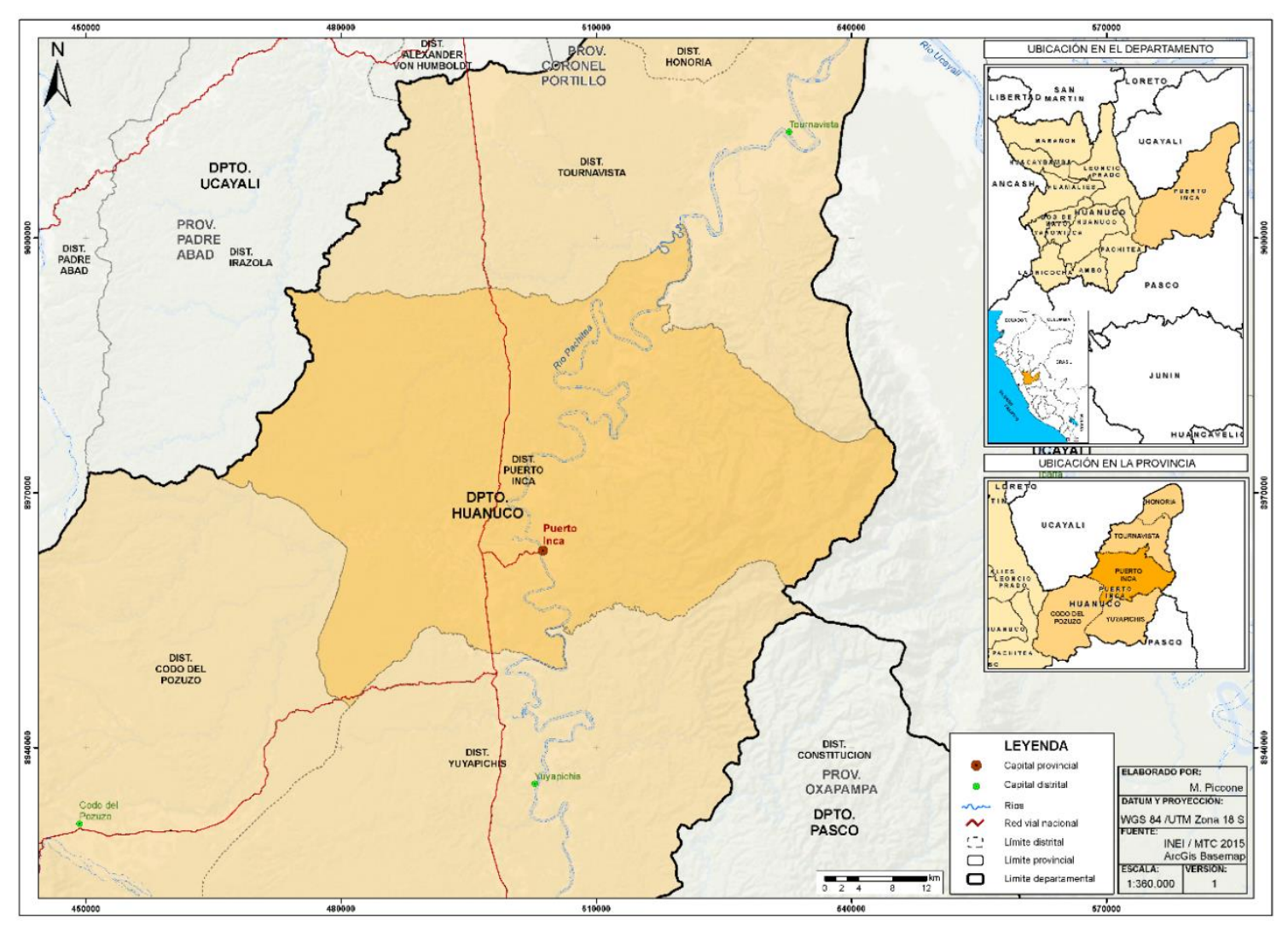

Figura 1. Localização das plantações de Guazuma crinita em Huánuco (Peru)

Figure 1. Plantation of Guazuma crinita en Huánuco (Perú).

\section{Cut, collect and preparation of the wood samples}

In the moment of the cut the trees were five years old (63 months) and others, eight years old (103 months). Five trees were selected by age following the Peruvian Technical Standard 251.008:2012; the ones that were cut, to what the comercial height measure were used, dividing in three part (basal, middle and apical), meeting

FLORESTA, Curitiba, PR, v. 50, n. 2, p. 1143 - 1150, abr/jun 2020.

Custodio, M. C. et.al.

ISSN eletrônico 1982-4688

DOI: $10.5380 /$ rf.v50 i2.58356 
the methodology Valente et al. (2013), taking a meter of each peace of the inferior portion to determinate the density and evaluate the fibers. From the separeted meter, it was taken a $5 \mathrm{~cm}$ slice to the evaluation of the dimensions of the fibers (length, thickness of the wall, diameter of the lumen and total width), in three different parts of the trunk and three radial positions to each height. With the remaining wood, the basic density was determined (Figure 2).

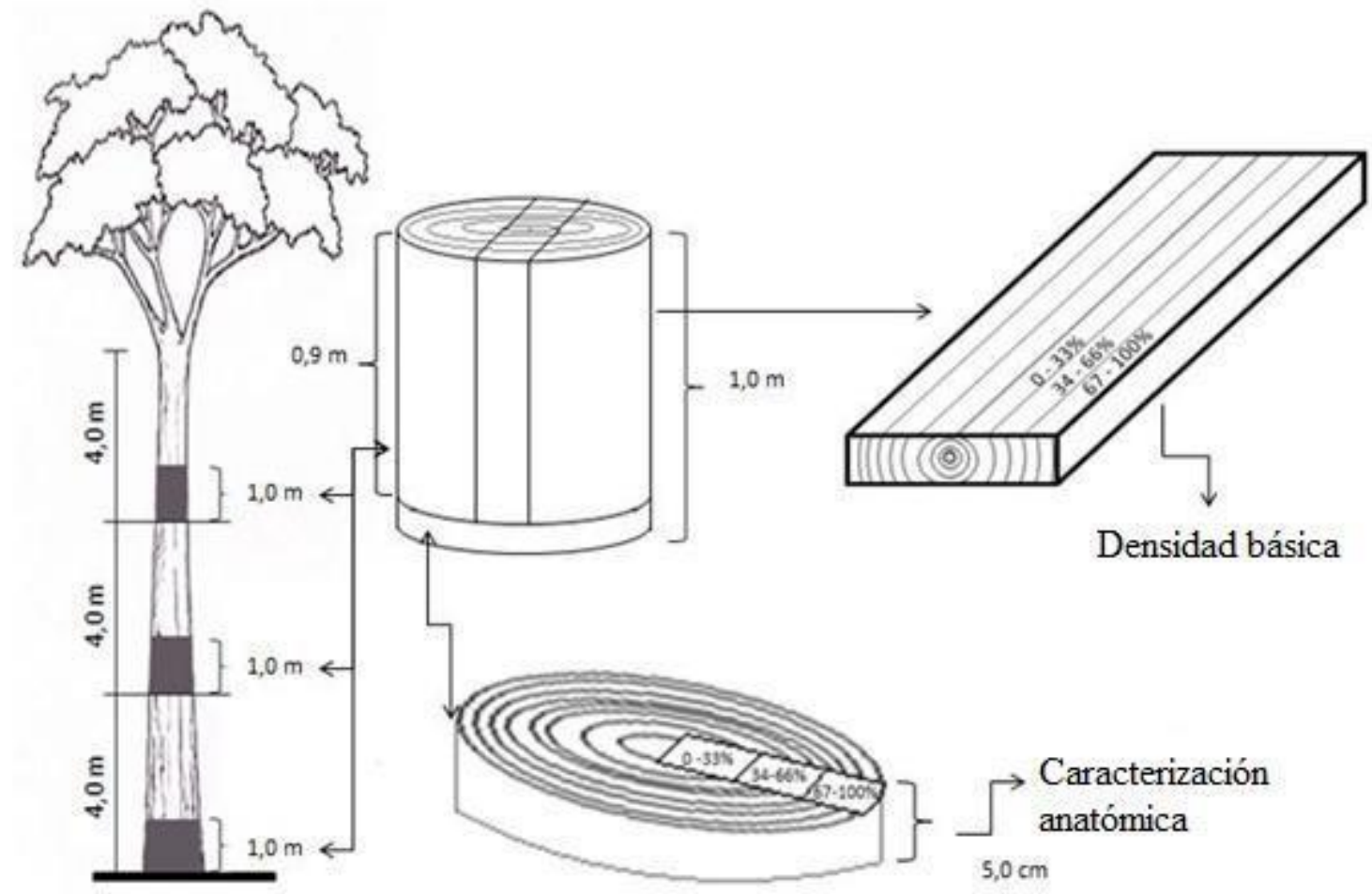

Figura 2. Posições das amostras para determinação da densidade básica e avaliação das fibras. Figura 2. Samples position for analysis of basic density and fiber dimension.

The analysis of the basic density was conduct according to the procedures described in the standard NTP 251.011: 2014. The discs, to the diffent heights of the five trees, were marked and cut samples in three radial positions in the direction marrow-cortex (at $1 / 3,2 / 3$ and $3 / 3$ of the marrow), to the acquisition of macerated material. To the fibers temporary histologic slides were prepared, gathering light microscopy images in ampliations of 40 and of 400x to the measurement of the dimensions of 25 fibers with the programme of image analysis "Leica Application", determinating length, width and diameter of the lumen, and estimating the thickness of the wall through half of the difference between width and diameter of the lumen.

\section{Statistical Analysis}

To the analysis of the data, the programme $\mathrm{R}$ was used, considering each tree as a repetition. The effect of the axial and radial positions was evaluated through the analysis of variance (ANOVA). At last, the Tukey test was applied with $95 \%$ of reliability, when the the differences between the effects were observed.

\section{RESULTS}

The average value and the variability coefficients of basic density and dimensions of the wood fiber of the Guazuma crinita to the two ages presented on the Table 2 and the tendencies of variation are observed in the Figure 3.

Tabela 2. Valores médios de densidade básica e dimensões de fibras de Guazuma crinita nas direções axial e radial.

Table 2. Mean value from basic density and fiber dimensions for Guazuma crinita in axial and radial direction. 


\begin{tabular}{|c|c|c|c|c|c|c|}
\hline \multicolumn{7}{|c|}{ Average Values } \\
\hline & & $\mathrm{DB}\left(\mathrm{g} / \mathrm{cm}^{3}\right)$ & $\mathbf{L}(\mathbf{m m})$ & $\mathrm{D}(\boldsymbol{\mu m})$ & $\mathrm{DL}(\boldsymbol{\mu m})$ & $\mathbf{E P}(\mu \mathrm{m})$ \\
\hline \multicolumn{2}{|c|}{$\begin{array}{c}5 \text { years } \\
\text { (63 months) } \\
8 \text { years } \\
\text { (103 months) }\end{array}$} & $\begin{array}{c}0.358 \\
(0.051)(14)^{1} \\
0.396 \\
(0.048)(12)\end{array}$ & $\begin{array}{c}1.369 \\
(0.186)(14) \\
1362 \\
(0.191)(14)\end{array}$ & $\begin{array}{c}28.050 \\
(5.056)(18) \\
26.947 \\
(5.163)(19)\end{array}$ & $\begin{array}{c}21.915 \\
(5.031)(23) \\
20.525 \\
(5.333)(26)\end{array}$ & $\begin{array}{c}3.071 \\
(0.655)(21) \\
3.204 \\
(0.615)(19)\end{array}$ \\
\hline \multicolumn{7}{|c|}{ Axial direction } \\
\hline \multirow{3}{*}{$\begin{array}{c}5 \text { years } \\
\text { (63 months) }\end{array}$} & Basal & $\begin{array}{c}0.405 \mathrm{a}^{2} \\
(0.03)(7)\end{array}$ & $\begin{array}{c}1.493 \mathrm{a} \\
(0.164)(11)\end{array}$ & $\begin{array}{c}27.526 \mathrm{~b} \\
(4.878)(18)\end{array}$ & $\begin{array}{c}21.292 \mathrm{~b} \\
(4.712)(22)\end{array}$ & $\begin{array}{c}3.12 \mathrm{a} \\
(0.593)(19)\end{array}$ \\
\hline & Intermedia & $\begin{array}{c}0.350 \mathrm{~b} \\
(0.042)(12)\end{array}$ & $\begin{array}{c}1.334 \mathrm{~b} \\
(0.154)(12)\end{array}$ & $\begin{array}{c}28.001 \mathrm{ab} \\
(4.617)(16)\end{array}$ & $\begin{array}{c}21.613 \mathrm{~b} \\
(4.639)(21)\end{array}$ & $\begin{array}{c}3.198 \mathrm{a} \\
(0.709)(22)\end{array}$ \\
\hline & Apex & $\begin{array}{c}0.340 \mathrm{c} \\
(0.043)(13)\end{array}$ & $\begin{array}{c}1.279 \mathrm{c} \\
(0.168)(13)\end{array}$ & $\begin{array}{c}28.624 \mathrm{a} \\
(5.577)(19)\end{array}$ & $\begin{array}{c}22.84 \mathrm{a} \\
(5.567)(24)\end{array}$ & $\begin{array}{c}2.896 \mathrm{~b} \\
(0.619)(21)\end{array}$ \\
\hline \multirow{4}{*}{$\begin{array}{c}8 \text { years } \\
\text { (103 months) }\end{array}$} & Basal & $\begin{array}{l}0.426 \mathrm{a} \\
\quad(0.040)(9)\end{array}$ & $\begin{array}{c}1.408 \mathrm{a} \\
(0.206)(15)\end{array}$ & $\begin{array}{c}27.232 \mathrm{a} \\
(5.509)(20)\end{array}$ & $\begin{array}{c}20.702 \mathrm{ab} \\
(5.845)(28)\end{array}$ & $\begin{array}{c}3.265 \mathrm{a} \\
(0.646)(20)\end{array}$ \\
\hline & Intermedia & $\begin{array}{c}0.395 \mathrm{~b} \\
(0.043)(11)\end{array}$ & $\begin{array}{c}1.379 \mathrm{a} \\
(0.174)(13)\end{array}$ & $\begin{array}{c}26.323 \mathrm{~b} \\
(4.881)(19)\end{array}$ & $\begin{array}{c}19.952 \mathrm{~b} \\
(4.885)(24)\end{array}$ & $\begin{array}{c}3.166 \mathrm{a} \\
(0.556)(18)\end{array}$ \\
\hline & Apex & $\begin{array}{c}0.365 \mathrm{c} \\
(0.038)(10) \\
\end{array}$ & $\begin{array}{c}1.302 \mathrm{~b} \\
(0.177)(14) \\
\end{array}$ & $\begin{array}{c}27.285 \mathrm{a} \\
(5.036)(18) \\
\end{array}$ & $\begin{array}{c}20.922 \mathrm{a} \\
(5.189)(25) \\
\end{array}$ & $\begin{array}{c}3.182 \mathrm{a} \\
(0.640)(20) \\
\end{array}$ \\
\hline & \multicolumn{6}{|c|}{ Radial direction } \\
\hline \multirow{3}{*}{$\begin{array}{c}5 \text { years } \\
\text { (63 months) }\end{array}$} & $1(0-33 \%)$ & $\begin{array}{c}0.357 \mathrm{a} \\
(0.057)(16)\end{array}$ & $\begin{array}{c}1.267 \mathrm{c} \\
(0.195)(15)\end{array}$ & $\begin{array}{c}28.37 \mathrm{a} \\
(5.140)(18)\end{array}$ & $\begin{array}{c}22.406 \mathrm{a} \\
(5.098)(23)\end{array}$ & $\begin{array}{c}2.982 \mathrm{~b} \\
(0.569)(19)\end{array}$ \\
\hline & $2(34-66 \%)$ & $\begin{array}{c}0.353 \mathrm{a} \\
(0.050)(14)\end{array}$ & $\begin{array}{c}1.390 \mathrm{~b} \\
(0.166)(12)\end{array}$ & $\begin{array}{c}27.787 \mathrm{a} \\
(5.087)(18)\end{array}$ & $\begin{array}{c}21.685 \mathrm{a} \\
(5.091)(23)\end{array}$ & $\begin{array}{c}3.06 \mathrm{ab} \\
(0.673)(22)\end{array}$ \\
\hline & $\begin{array}{c}3(67- \\
100 \%)\end{array}$ & $\begin{array}{c}0.363 \mathrm{a} \\
(0.045)(12)\end{array}$ & $\begin{array}{c}1.449 \mathrm{a} \\
(0.144)(10)\end{array}$ & $\begin{array}{c}27.994 \mathrm{a} \\
(4.934)(18)\end{array}$ & $\begin{array}{c}21.655 \mathrm{a} \\
(4.878)(23)\end{array}$ & $\begin{array}{c}3.171 \mathrm{a} \\
(0.701)(22)\end{array}$ \\
\hline \multirow{3}{*}{$\begin{array}{c}8 \text { years } \\
\text { (103 months) }\end{array}$} & $1(0-33 \%)$ & $\begin{array}{c}0.392 \mathrm{~b} \\
(0.053)(14)\end{array}$ & $\begin{array}{c}1.243 \mathrm{c} \\
(0.164)(13)\end{array}$ & $\begin{array}{c}28.037 \mathrm{a} \\
(5.029)(18)\end{array}$ & $\begin{array}{c}21.833 \mathrm{a} \\
(5.114)(23)\end{array}$ & $\begin{array}{c}3.082 \mathrm{c} \\
(0.618)(20)\end{array}$ \\
\hline & $2(34-66 \%)$ & $\begin{array}{c}0.379 \mathrm{~b} \\
(0.050)(13)\end{array}$ & $\begin{array}{c}1.396 \mathrm{~b} \\
(0.174)(12)\end{array}$ & $\begin{array}{c}26.721 \mathrm{~b} \\
(5.534)(21)\end{array}$ & $\begin{array}{c}20.299 \mathrm{~b} \\
(5.703)(28)\end{array}$ & $\begin{array}{c}3.211 \mathrm{~b} \\
(0.569)(18)\end{array}$ \\
\hline & $\begin{array}{c}3(67- \\
100 \%)\end{array}$ & $\begin{array}{c}0.415 \mathrm{a} \\
(0.032)(8)\end{array}$ & $\begin{array}{c}1.450 \mathrm{a} \\
(0.173)(12)\end{array}$ & $\begin{array}{c}26.082 \mathrm{~b} \\
(4.712)(18)\end{array}$ & $\begin{array}{c}19.444 \mathrm{~b} \\
(4.885)(25)\end{array}$ & $\begin{array}{c}3.319 \mathrm{a} \\
(0.639)(19)\end{array}$ \\
\hline
\end{tabular}

DB: densidade básica; L: comprimento das fibras; D: diámetro das fibras; DL: diámetro de lumen; EP: espessura da parede das fibras; 1 : medula; 2 : intermédia; 3 : córtex; ${ }^{1}$ Valores entre parénteses de esquerda à direita debaixo do promédio, correspondem ao desvio padrão e a coeficiente de variação respectivamente; ${ }^{2}$ Médias seguidas da mesma letra dentro de uma mesma coluna, não diferen estatisticamente entre sí, pelo teste de Tukey $(\mathrm{p}>0,05)$.
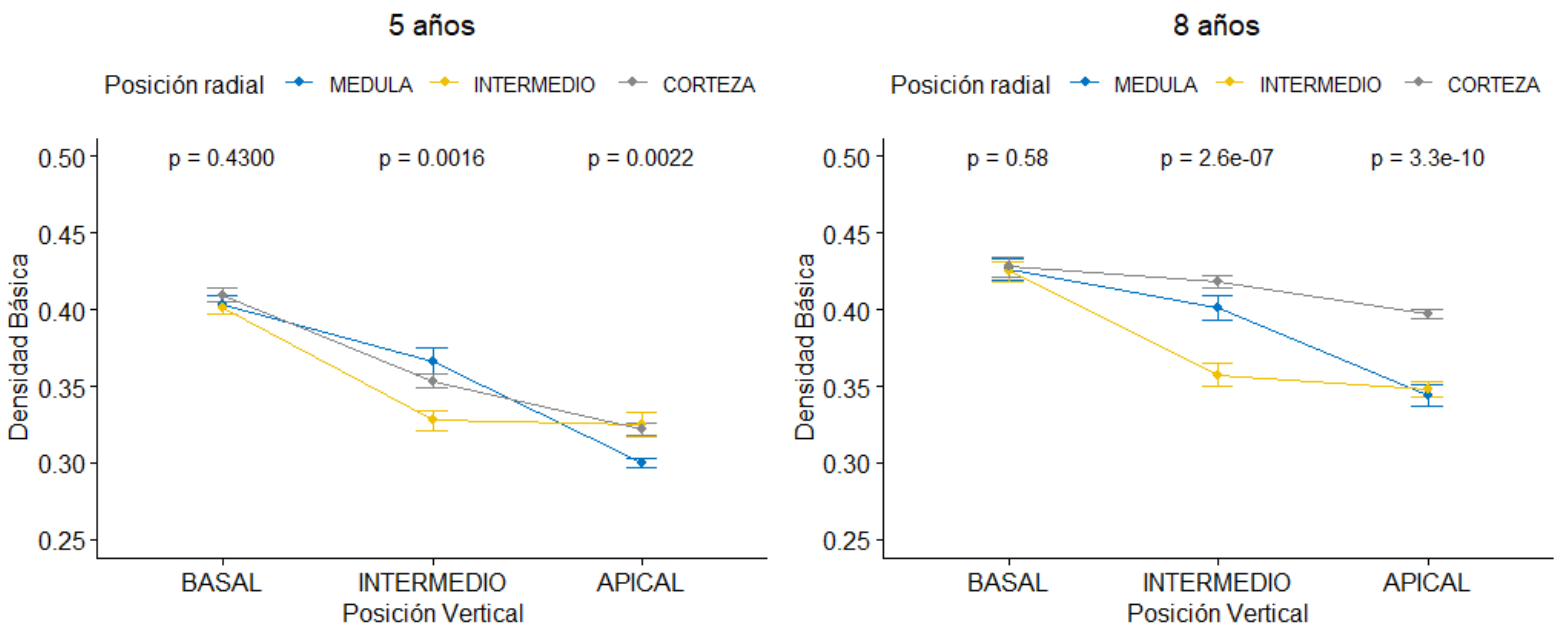

FLORESTA, Curitiba, PR, v. 50, n. 2, p. 1143 - 1150, abr/jun 2020

Custodio, M. C. et.al.

ISSN eletrônico 1982-4688

DOI: $10.5380 /$ rf.v50 i 2.58356 
5 años



5 años

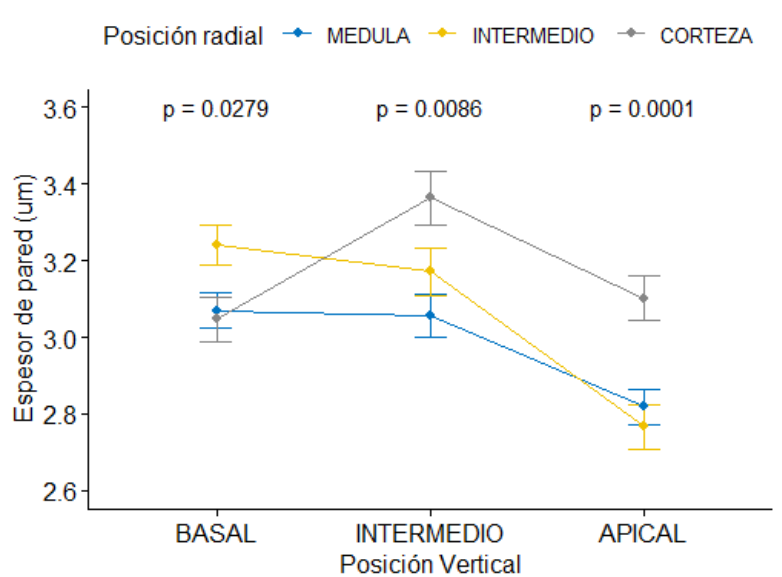

8 años

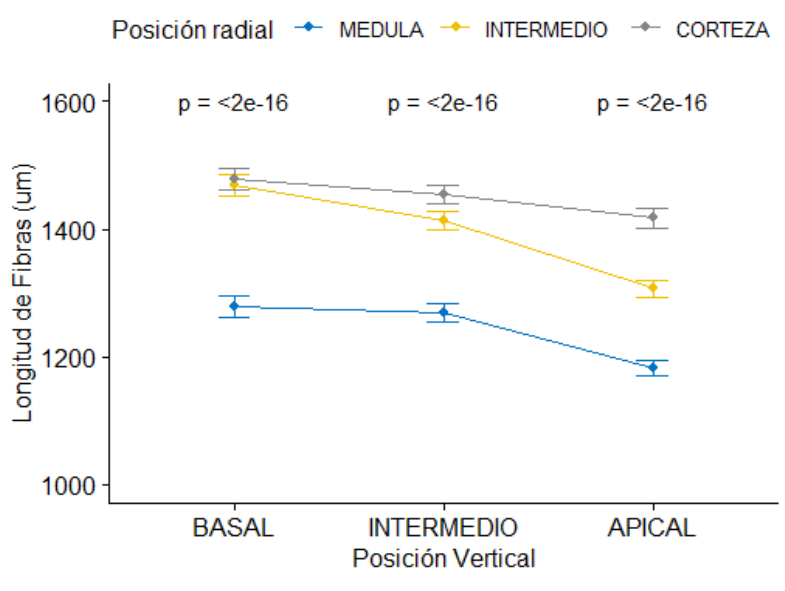

8 años

Posición radial $\rightarrow$ MEDULA $\rightarrow$ INTERMEDIO $\rightarrow$ CORTEZA

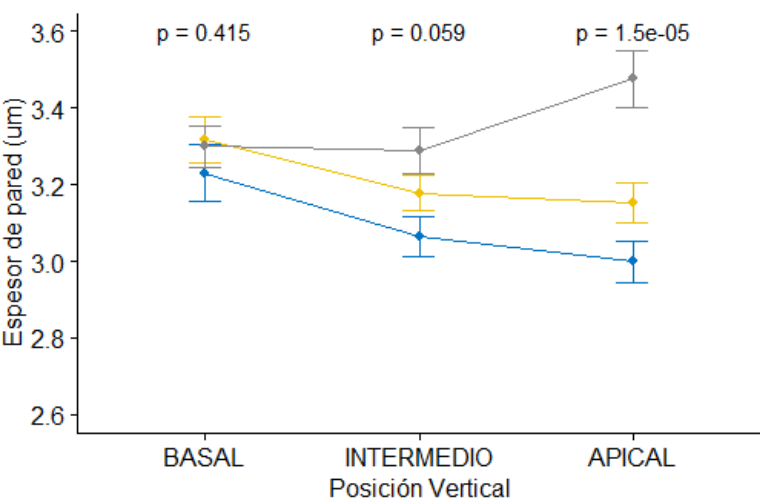

Figura 3. Padrões de variação axial e radial para a densidade básica, comprimento e espessura da parede das fibras para 5 e 8 anos.

Figure 3. Patterns of axial and radial variation for basic density, fibers length and fiber wall thickness for 5 and 8 years.

\section{DISCUSSION}

It is noted that the average values of basic density increase from 0,377 to $0,396 \mathrm{~g} / \mathrm{cm}^{3}$ to the ages of 5 and 8 years respectively. The values decrease from the base to the apex, and at the same time in the radial direction increase from the marrow to the cortex (Figure 2). In both directions there are statistics differences to the three positions; except in the radial direction to the 1 and 2 positions, which are statiscally equal to the age of 5 years and to the 1 position close the marrow, that is bigger than the intermediate position to the age of 5 years.

The collected values of density are smaller that the one related by Weber and Sotelo-Montes (2008) to the same age. In the axial direction the basic density decreases from the base to the tree top, which is explained by the bigger compression of the tissues due to the overlapping of cells along the trunk and the tree top (ALI et al., 2010); even so, this variation arise from the different radial and longitudinal positions (WEBER; SOTELOMONTES, 2008; TUISIMA-CORAL et al., 2017; TRAUTENMÜLLER et al., 2014). The radial behavior of increase of the basic density of the marrow in direction the cotex is related in other broad-leafed plants such as Anadenanthera peregrina (VALENTE et al., 2013) e em plantações de Tectona grandis (LIMA et al., 2011).

In the fibers length, to both ages the values are similar; axially it is observed a decrease from the base to the apex; and only to the basal and intermediate portion to the age of 8 years there are no statistics differences between them. Radially statistic differences are presented to the three positions with a increase of the marrow in direction to the cortex (Figure 2). In the diameter of the fibers there is no dtermined tendency; although, axially to both ages higher values in apex portion are noted; at the same time, to 8 years the basal and apex level are statistically equal, but higher in the intermediate level. Radially, to the age of 5 years there are no statistic 
differences in the 3 positions; and to 8 years the positions 2 and 3 are equal, but with lower values closer to the marrow.

As for the diameter of the lumen longitudinally, to the age of 5 years it is bigger in the apex portion than in basal and intermediate level, which are statiscally equal; to 8 years the basal level has an interaction with the intermediate and apex levels. In the radial direction, to both ages there are no statistic differences between them; except in the position 1, close to the marrow, that has higher value than the position 2 and 3 .

In the thickness of the wall of the fiber this value increases with the age and axially tends to be homogeneous, except to the apex level at 5 years, which is lower. Radially an increase was noted in the marrowcortex direction; with significant statistic difference in the 3 positions to both ages, except position 2 at 5 years.

Altogether, the values obtained to fibers in the present studuy are slightly higher than the ones obtained in the anatomical evaluation in the Guazuma crinita in natural forest situation, which related a length of $657 \mu \mathrm{m}$, fiber diameter of $18 \mu \mathrm{m}$ and thickness of the wall of $3 \mu \mathrm{m}$ (ACEVEDO; KIKATA, 1994).

This same pattern of axial and radial variation was found to length and thickness of the wall of the fibers to other broad-leafed plants; similarly em axial direction to the Anadenanthera colubrina (SUCKOW et al., 2009) and in radial direction to the Anadenanthera peregrina (VALENTE et al., 2013) and (Parkia gigantocarpa (MIRANDA; CASTELO, 2012).

The variability coefficient to the DB is $14 \%$ to 5 years and $12 \%$ to 8 years. Although, to the Ficus insipida coefficients of variation of 5,99\% to $39,1 \%$ are found (VIDAL et al., 2011). To the Anadenanthera peregrina Valente et al. (2013) reports a variability coefficient of 17,86\%; in contrast, Trautenmüller et al. (2014) finds variability coefficients $5,2 \%$ and $12,54 \%$ to the basic density in Cordia americana and Alchornea triplinervia respectively.

The variability coefficients found (Table 2) are within the range noted by other authors and, as for specific characteristics, can be considered slightly high. This differences are possibly due to the individual variability among five trees of the G. crinita, and mainly due to age. It is important to add thatv Igartúa and Monteoliva (2010), quoting Wilkes (1988), note that difference among trees in the same location and age can be found.

Altogether, the average anatomical values to both ages are similar; however, the density to 8 year is higher and its use could be in comercial scale that does not require to endure big efforts.

\section{CONCLUSIONS}

According to the obtained results to basic density and anatoic characteristics of the Grazuma crinita to 5 and 8 years it possible to conclude that:

- The basic density and length of the fibers present significant variations in the axial and radial directions to both ages.

- The diameter of the fiber does not show determined tendency to both directions; although the diameter of the lumen presents significant difference in the axial direction, but not in the radial direction.

- The thickness of the wall to both ages presents significant differences in the radial direction, but not in the axial direction.

- Altogether, the basic density and anatomial characteristics evaluated decrease from the base to the apex, it increases from the marrow to the cortex.

- The age variable had significant influence over the basic density, but not over the anatomical characteristics.

\section{AKNOWLEDGEMENTS}

Thanks to the Enterprise Reforestadora Amazónica S.A. (RAMSA), for the given material and for the support in the material collection.

\section{BIBLIOGRAPHY}

ACEVEDO, M.; KIKATA, J. Atlas de maderas del Perú. Lima: Universidad Nacional Agraria la Molina, 1994.

ALI, C; CHIRKOVA, J; TERZIEV, N; ELOWSON, T. Physical properties of two tropical wood species from Mozambique. Wood Material Science and Engineering, London, v. 5, n. 3, p. 151-161, 2010.

ANDRADE, M.; LONGUI, L; LIMA, L; FLORSHEIM, S. Efeito da procedência na variação radial do comprimento das fibras e densidade básica de Gallesia integrifolia (Spreng.) Harms. Instituto Florestal Serie Registros, São Paulo, v. 40, p.39-43, 2009.

GARCIA, M.F.; FLORSHEIM, S.M.B.; LIMA, I.L.; LONGUI, E.L. Variação radial da densidade básica e comprimento de fibras de diferentes procedências de Cariniana legalis. Instituto Florestal Serie Registros, São Paulo, v. 40, p. 75-80, 2009.

FLORESTA, Curitiba, PR, v. 50, n. 2, p. 1143 - 1150, abr/jun 2020

Custodio, M. C. et.al.

ISSN eletrônico 1982-4688

DOI: $10.5380 /$ rf.v50 i2.58356 
IGARTÚA, D.; MONTEOLIVA, S. Densidad básica, longitud de fibras y crecimiento en dos procedencias de Eucalyptus globulus en Argentina. Bosque, Buenos Aires, v. 31, n. 2, p. 150-156, 2010.

INSTITUTO DE INVESTIGACIÓN DE LA AMAZONÍA PERUANA (IIAP). Evaluación económica de parcelas de regeneración natural y plantaciones de bolaina blanca, Guazuma crinita, en el departamento de Ucayali. Avance Económico. IIAP, Iquitos, 2009.

INSTITUTO NACIONAL DE CALIDAD (INACAL). NTP 251.008:2012. Maderas. Selección y colección de muestras. 2012.

INSTITUTO NACIONAL DE CALIDAD (INACAL). NTP 251.011:2014. Madera. Método para determinar la densidad. 2014.

LEON, W. Variabilidad de la madera de Swietenia macrophylla King proveniente de plantaciones de 10 años de edad (Caparo, estado Barinas, Venezuela). Revista Forestal Venezolana, Mérida, v. 54, n. 2, p. 169-182, 2010.

LIMA. L.; PIMENTEL, M; GARCIA, N. Propriedades mecânicas e densidade aparente da madeira de Tectona grandis Linn. F. (Teca) em função do espaçamento e da posição radial na tora. Silva Lusitana, Oeiras, v. 19, n. 2 , p. $221-232,2011$.

LONGUI, L; LIMA, L; JUNIOR, S; BUFOLO, A; SUCKOW, S; FLORSHEIM, S. Variação radial das características anatômicas, densidade aparente, teores de extrativos, lignina e holocelulose na madeira de Piptadenia gonoacantha (Mart.) Macbr. Scientia Forestalis, Piracicaba, v. 38, n. 87, p. 341-353, 2010.

MIRANDA, M.C.; CASTELO, P.A.R. Avaliações anatômicas das fibras da madeira de Parkia gigantocarpa Ducke. Ciência da Madeira, Pelotas, v. 3, n. 2, 2012.

PORTAL, L.A.; LATORRACA, J.V; PACE, J.H.; DOS SANTOS, G.C.; LIMA, D.; RAMOS, L.M.; DO CARMO, J. Variabilidad radial física y anatómica del leño de árboles de Amburana cearensis (Allemao) A.C.Sm. Colombia Forestal, Bogotá, v. 22, n. 1, p. 17-26, 2019.

PUTZEL, L.; CRONKLETON, P.; LARSON, A.; PINEDO-VÁSQUEZ, M.; SALAZAR, O; SEARS, R. Producción y comercialización de Bolaina (Guazuma crinita), una especie amazónica de rápido crecimiento. Boletín Brief. n. 25, p. 6, 2013.

REYNEL, C.; PENNINGTON, R.; PENNINGTON, T.; FLORES, D.; DAZA, C. Árboles útiles de la Amazonía Peruana, Manual de identificación ecológica y propagación de las especies. Lima: Universidad NacionalAgraria La Molina, 2003.

SERVICIO NACIONAL FORESTAL Y DE FAUNA SILVESTRE (SERFOR). Anuario Forestal y de Fauna Silvestre 2016. Lima: Ministerio de Agricultura y Riego, 2016.

SOUDRE, M. Plantaciones de Guazuma crinita. Entrevista personal. Pucallpa. 2019.

SUCKOW, S.; LONGUI, L.; LIMA, L; FLORSHEIM, S.; AGUIAR, T. Anatomia da madeira e densidade básica de angico-branco Anadenanthera colubrina (Vell.) Brenan. Instituto Florestal Serie Registros, São Paulo, v. 40, p. 131-135, 2009.

TRAUTENMÜLlER, W; BALBINOT, R.; BORELlA, J.; TREVISAN, R.; BALESTRIN, D.; VENDRUSCOLO, R.; SABADINI, M. Variação longitudinal da massa específica básica da madeira de Cordia americana e Alchornea triplinervia. Ciência Rural, Santa Maria, v. 44, n. 5, p. 817-821, 2014.

TUISIMA-CORAL, L; ODICIO-GUEVARA, E; WEBER, C; LLUNCOR-MENDOZA, D.; LOJKA, B. Variation in woodphysical properties within stems of Guazuma crinita, a timber tree species in the Peruvian Amazon. Madera y Bosques, Xalap, v. 23, n. 1, p. 53-61, 2017.

VALENTE, T; EVANGELISTA, V; SILVA, C; DELLA LUCIA, R.M. Variabilidade radial e longitudinal das propriedades físicas e anatômicas da madeira de Angico-Vermelho. Scientia Forestalis, Piracicaba, v. 41, n. 100, p. 485-496, 2013.

VIDAL, J.; VELÁSQUEZ, J.; TORO, M.; GÓMEZ, L. Variación natural del peso específico en la madera de Ficus insipida Will (Moraceae). Revista Forestal Venezolana, Mérida, v. 55, n. 1, p. 17-22, 2011.

WEBER, C; SOTELO-MONTES, C. Geographic variation in tree growth and wood density of Guazumacrinite Mart. in the Peruvian Amazon. New Forest, v. 36, p. 29-52, 2008.

WEBER, J; SOTELO MONTES, C.; CORNELIUS, J.; UGARTE-GUERRA, J. Genetic variation in tree growth, stem form and mortality of Guazuma crinita in slower- and faster-growing plantations in the Peruvian Amazon. Silvae Genetica,v. 60, n. 2, p. 70-78, 2011.

ZANON, R; LONGUI, E.; FLORSHEIM, S.; LIMA, I. Variação radial da densidade básica e dimensões celulares de Croton floribunda Spreng na Serra da Cantareira, SP. Instituto Florestal Serie Registros, São Paulo, v. 36, p. 25-29, 2008.

FLORESTA, Curitiba, PR, v. 50, n. 2, p. 1143 - 1150, abr/jun 2020 